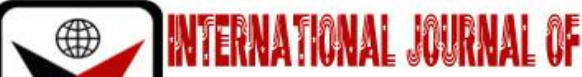 \\ בmas
}

ISSN 2278 - 0211 (Online)

\section{Grammatical Misapplication of a Verb-Tense: The 3rd Person Singular Popular Usage Error in the Present Simple Tense}

\author{
Ahmad Muhammad Mahmoud \\ Lecturer, Department of English, School of Languages \\ Aminu Saleh College of Education, Azare, Bauchi state, Nigeria
}

\begin{abstract}
:
The write-up is deliberately and even intentionally developed to seriously call attention of the second language (L2) speakers and writers of English language upon the usage error of the present simple tense unknowingly spoken or written usually or occasionally, particularly when it comes to the $3^{\text {rd }}$ person singular as a subject of a clause or sentence. It also, as a matter of recommendation draws the attention of English language teachers to put more effort in making teaching-learning process effective, especially for the successful communication skill acquisition expected of English students and other classroom teachers in Nigeria and beyond.
\end{abstract}

Keywords: Simple present tense, usage error, and $3^{\text {rd }}$ person singular rules

\section{Introduction}

The second language classroom like any other school classrooms is normally a formal set up of a well-ventilated building meant to accommodate language students (the L2 learners) and their teacher for language lesson periods. Some of the private secondary schools and higher institutions have language laboratories for teaching language of any kind, depending on the community or societal language background. A learner of a second language (L2) simply denotes somebody who learns another language rather than or in addition to that of his or her mother tongue. Each and every language either spoken or written has to have some certain rules which directly or indirectly, that is, formally or informally guide the listener or reader understands or interprets the message being sent from the source, particularly regarding the actual or specific time of the said action. And this has to do with any of the forms of a verb which distinguishes when an action or state of being occurs in a tense, and it is of course the element of grammar as the communicative requirement of discussions or transactions among individuals and groups. Grammar however, has to do with the conventions which govern the relationships between words in language of any kind. In specification, the simple present tense as a point of discussion, expresses events or situations that exist always, usually, habitually; they exist now, have existed in the past and probably will exist in the future (Azar, 2002). This element of unspecific direction within the tense attracts a certain rule which seriously invites the attention of the L2 learner of English language especially in the case of $3^{\text {rd }}$ person singular. The study at hand therefore, analyses errors on present simple tense among the English language learners in Nigeria. It directly focuses on the error on 3psg $-s$ (the third person singular present tense agreement morpheme $-s$ ) which is normally unknowingly neglected by almost most of the speakers or writers of English as a second language (Muftah and Rafik, 2013).

\section{Method}

The data collected has been systematically methodized via academic lectures, classroom discussions with students, during marking students' scripts, in the markets, on the streets, and some other gatherings where people use English language as their medium of interactions.

\subsection{Present Simple Tense}

The present tense is actually made up of four aspects which include the present tense it self, present progressive, present perfect and present perfect continuous tense. But in normal circumstances however, each of them is treated individually as a tense. They are a combination of the present tense and aspect (Herring, 2016). That means the tense indicates when the actual action takes place while the aspect notifies the information about how the happening happens in relation to time. The present simple and present progressive tenses are the common ways of expressing present time in English (Hall and Forley, 2003) because it normally describes things that are true at the time of speaking but may accommodate a change when necessary. Academic books and their likes are mostly written by making use of present simple tense, likewise other verbal orations. But unfortunately, many non-native speakers of English continue to omit the ' $\mathrm{s}$ ' when using third person singular. There is need to be remembering the ' $\mathrm{s}$ ' using the present affirmative in order to do away with the subject-verb disagreement of sounds and structures (Melvin, 2014).The basic negative simple present is 
formed with 'not' though there has to be an auxiliary verb in use, either 'do' or 'does' (Raifsnaida, 2000).The pattern should be subject $+\mathrm{AV}$ do or does + not + MV without -s. Likewise, single-word adverbs of frequency like always, usually, often, etc. are sometimes used (Krohn, 1997). Hudson (2010) ensures that a present tense verb agrees in number with its subject (e.g. he signs but they sign)'.the simple present tense can also be used to express future time in sentences that concern events that are on a definite schedule or timetable, and these sentences usually contain future time words. Such a few verbs used include: starts, begins, finishes, opens, closes, ends, returns, arrives, leaves, comes, and their likes (Azar,2002).In this regard, Murphy (2019) emphasizes: 'we use the present simple to talk about things in general. We use it to say something happens all the time or repeatedly, or that something is true in general.'

\subsection{Usage Error or Ungrammatical Structures}

A countless practices and drills on tenses constitute a significant portion of the process of teaching and learning English as a second language, yet much researches had been done in the last few decades on the factors causing errors in the learning of some tenses, particularly the present simple tense, is still far from being conclusive. Focusing on the present simple tense, this journal argues that a large portion of the errors in the use of the tense may be ascribed to both intralinguas interference resulting from the idiosyncrasies of the rules governing the use of tenses and certain Interlinguas differences especially with regard to temporal references of verb phrases (Miin, 2003). Of course grammarians have been observing people of different educational backgrounds speaking English with the problem of disagreement between subject and the verb of present simple tense. Such incorrect structures include 'He don't know her' instead of 'He doesn't know her' or 'He know her' in place of 'he knows her'. Other examples are: 'Ameer read the novel every day' for 'Ameer reads the novel everyday' or 'Amatu cook the rice' when saying 'Amatu cooks the rice'. The same problem usually happens when it comes to writing such utterances, people write something like 'Bilal wash his school uniform every morning' in his effort to compose 'Bilal washeshis school uniform every morning'. A lot of such negative instances have been happening here and there in our daily interactions, daily write ups and even the academic compositions written by some of the academicians and students. The rule of correct and grammatical use of third person singular is totally ignored by a number of speakers of English as a second language (L2).

\subsection{Grammatical Rules of the Third Person Singular}

(The regular and irregular verb cases)

The rules governing the correct and grammatical expression of the $3^{\text {rd }}$ person singular when speaking or writing in the present simple tense are illustrated hereunder:

1. Normally, 'S' is added to the end of the verb in the 3rd person singular (noun or pronoun subject). The simple illustration is shown below:

\begin{tabular}{|c|c|}
\hline Verb & 3rd Person Singular \\
\hline Eat & She eats \\
\hline read & He reads \\
\hline write & Musa writes \\
\hline drive & Mary drives \\
\hline
\end{tabular}

The second rule has to do with a verb which naturally ends in SS, X, CH, SH or letter O. in this case, the 'es' morphemeis added to the verbin the third person singular (noun or pronoun subject). The substitution table below has the details:

\begin{tabular}{|c|c|}
\hline Verb & 3rd Person singular \\
\hline miss & She misses \\
\hline fix & He fixes \\
\hline watch & Isa watches \\
\hline push & Joy pushes \\
\hline do & Adam does \\
\hline
\end{tabular}

Table 2

Thirdly and finally, If the verb ends in a Consonant ' $\mathrm{Y}$ ', the ' $\mathrm{Y}$ ' is removed and replaced with'es'in the third person singular (noun or pronoun subject) as also exemplified in the table here:

\begin{tabular}{|c|c|}
\hline Verb & 3rd Person singular \\
\hline carry & He carries \\
\hline study & She studies \\
\hline try & Isaac tries \\
\hline deny & Mary denies \\
\hline \multicolumn{2}{|c}{ Table 3 }
\end{tabular}


However, simple present tense with verbs other than becomes with Statement like he reads, Question with do, does: Does he play? Or short answers like Yes, he does.

\section{Conclusion/Recommendation}

English language has officially become the medium of instruction in schools and of course the language in use for other official transactions and interactions by almost all the employed personnel of the Nigerian government and even non-governmental enterprise employees. In this regard, the language has to be learnt effectively in order to escape from communication abuse of any kind. However, this study strongly recommends that English teachers should always emphasize on teaching their students tenses, especially present simple tense which specifically has some rules governing third-person singular functioning as a subject of a clause or sentence. English teachers are also advised to avoid ignoring pointing out such usage errors when marking argumentative, expository and descriptive essays written by their students, likewise other class works and exercises. Instant correction must alwaysbe encouraged when verbally speaking the language wrongly by other second language learners either in the classrooms or outside the classroom.People speaking English language in the markets and any other places will be politely corrected when mistake of any kind is made.

\section{Reference}

i. Azar, B. S. (2002). Understanding English grammar. Prentise-Hall International: London.

ii. Hall, D. \& Forley, M. (2003). Advanced learners' grammar; a self-study reference and practice book. Longman publishers: England.

iii. Herring, P. (2016). Complete English grammar rules. Ferlexinter national: London.

iv. Hudson, R. (2010). An introduction to the word grammar. Cambridge University Press:New York.

v. Krohn, R. (1997). English sentence structure. University of Michigan press: USA.

vi. Melvin, J. (2014). English grammar reference book. Cambridge University Press: New York

vii. Minn, J.H. (2003). Interference in the second language acquisition of the present simple tense, Asian journal of English language teaching, 13, 1-28, Chinese university press: Sabah.

viii. Muftah, M. and Rafik-Galea, S. (2013). Error analysis of present simple tense in the inter-language of adult Arab English language learners. English language teaching Vol 6. No. 2. Canadian printers: Canada.

ix. Murphy, R. (2019). English grammar in use. Cambridge University Press: New York.

x. Raifsnaida, B. (2000). Fluent English for speakers of every language.Ferlex international: London. 